\title{
Peningkatan Kualitas Penulisan Artikel Ilmiah bagi Kepala Sekolah
}

\author{
Zadrian Ardi ${ }^{1}$, Erlamsyah E rlamsyah ${ }^{2}$, Ifdil Ifdil3 \\ ${ }^{123}$ Universitas Negeri Padang \\ *Corresponding author, e-mail: zadrian@fip.unp.ac.id
}

\begin{abstract}
The principal as a social worker has thousands and even millions of aspects and scope of scholarship that can be used as material for scientific development, especially related to the development of learning process and improvement of learning. As a professional, social workers including counselors, psychologists and policy-makers such as principals are urgently needed to develop their insights and knowledge of human and territorial behavior that can be addressed through counseling services. Various things will certainly be realized by the research or research and publish through scientific articles. But in reality, the principal has not been too concerned and develop the ability and competence in the field of scientific articles. Various cases and services that should be used as material for scientific and professional discussions are not published in the form of scientific articles so that in general the parameters of the development of learning and service BK in the school cannot be known with certainty. These conditions require the principal to have the competence and skills in writing scientific articles and using digital citation program / software.
\end{abstract}

Keywords: Quality of Educational, teacher profesionalism, Headmaster, scientific manuscript
Received October 29, 2017;

Revised November 22, 2017;

Accepted December 25, 2017;

Published Online January, 2018

Conflict of Interest Disclosures: The authors declare that they have no significant competing financial, professional or personal interests that might have influenced the performance or presentation of the work described in this manuscript.

\section{(c) (1)}

This is an open access article distributed under the Creative Commons 4.0 Attribution License, which permits unrestricted use, distribution, and unrestricted use, distribution, and
reproduction in any medium, provided the original work is properly cited. C2017 by author

How to Cite: Ardi, Z., \& Erlamsyah, E. I, Ifdil (2017). Peningkatan Kualitas Penulisan Artikel Ilmiah bagi Kepala Sekolah. Jurnal Aplikasi IPTEK Indonesia, 1(1), 11-15, DOI: 10.24036/4.114

\section{Pendahuluan}

Independensi dan kemajuan sebuah bangsa dapat terlihat dari kemajuan dan mutu eksplorasi keilmuan dari berbagai aspek kehidupannya, termasuk dalam hal keilmuan pendidikan. Perkembangan keilmuan sosial, yang dalam hal ini khususnya pendidikan terlihat sangat cepat dan progresif, bahkan menjadi sebuah kebutuhan bagi masyarakat ilmiah. Berbagai bangsa dan negara berbondong-bondong melakukan pengembangan keilmuan pada bidangnya, baik melalui penelitian dan riset maupun pemikiran mendalam serta kajian-kajian profesional.

Rekam jejak dari perkembangan ilmu akan dengan mudah dilacak oleh masyarakat ilmiah melalui berbagai bentuk informasi keilmuan. Hasil riset dan keilmuan merupakan komoditi yang penting dan berharga sehingga dapat dijadikan sebagai bahan dalam melakukan prediksi dan perancangan program di masa depan (Suyanto \& Jihad, 2014). Lebih khusus, pengembangan informasi ini perlu dilakukan oleh orang-orang yang berada pada kajian yang berkenaan dengan pengembangan dan kajian tingkah laku manusia. Sebagai salah satu kajian sosial, proses pengembangan informasi keilmuan akan dapat menjawab "apa dan mengapa" suatu tingkah laku itu muncul dalam ruang lingkup kehidupan sosial manusia, realitas sosial dan berbagai hal yang berkaitan dengan hal tersebut (Babbie, 2013).

Pekerja sosial memiliki ribuan bahkan jutaan aspek dan ruang lingkup keilmuan yang bisa dijadikan sebagai bahan untuk melakukan pengembangan keilmuan. Berbagai fenomena sosial yang terjadi di masyarakat dalam kurun waktu satu dekade terakhir pasti akan sangat berbeda dengan fenomena yang terjadi dua puluh atau bahkan tiga puluh tahun sebelumnya (Ardi, 2012). Kondisi-kondisi itulah yang akan dijadikan sebagai tambang potensial untuk melakukan pengembangan keilmuan. 
Sebagai seorang profesional, kepala sekolah sangat perlu untuk mengembangkan wawasan dan pengetahuannya mengenai perilaku manusia dan wilayah yang dapat ditangani melalui pelayanan konseling. Selain itu, perlu adanya evaluasi terhadap layanan yang telah diberikan serta beberapa hal yang mungkin perlu diperbaiki (Heppner, Wampold, \& Kivlighan Jr, 2008). Berbagai hal tersebut tentu akan dapat terwujud dengan adanya riset atau penelitian serta melakukan publikasi melalui artikel ilmiah.

Kepala sekolah dituntut untuk mampu mengembangkan kemampuan profesionalnya terkait dengan keilmuan di bidangnya dan dalam manajemen pendidikan di instansi yang menjadi tanggungjawabnya. Hal ini dapat diwujudkan dengan melakukan berbagai riset serta penulisan artikel tulis ilmiah (Marjohan, 2012). Sehingga dengan adanya riset dan artikel ilmiah tersebut kepala sekolah dapat mengembangkan keilmuan, melaporkan berbagai kasus-kasus tertentu yang perlu menjadi perhatian akademisi dan masyarakat ilmiah, mengembangkan karir, serta memberikan kontribusi terhadap dinamika keilmuan bimbingan dan konseling pada umumnya.

Namun pada kenyataannya, kepala sekolah belum terlalu memperhatikan dan mengembangkan kemampuan serta kompetensi pada bidang penulisan dan riset terkini, khususnya artikel ilmiah. Berbagai kasus dan pelayanan yang seharusnya dapat dijadikan bahan diskusi ilmiah dan profesional tidak dipublikasikan dalam bentuk artikel ilmiah sehingga secara umum parameter perkembangan siswa di sekolah belum dapat dipetakan dengan baik dan diketahui secara pasti.

Pertimbangan lain yang menjadi keprihatinan pada pengembangan keilmuan adalah minimnya perkembangan karir guru (khususnya kepala sekolah) yang menggunakan artikel ilmiah sebagai batu loncatan karirnya. Sebagaimana paparan data Kompas tanggal 22 April 2013, mengemukakan bahwa terdapat 800.000 orang guru di Indonesia yang stagnan perkembangan karirnya karena tidak mampu dalam melakukan publikasi hasil riset dan karya ilmiah.

Kenyataannya, potensi berbagai jenis jurnal di Indonesia (dengan standar yang sudah cukup bagus, yakni terindeks pada DOAJ) telah cukup banyak tersedia, seperti pada paparan Grafik 1.

Grafik 1 memaparkan bahwa pertumbuhan signifikan di Indonesia terjadi pada tahun 2009 sehingga bisa mengejar Malaysia, dan data terbaru pada 5 Juli 2017 menunjukkan bahwa jurnal terindeks DOAJ di Indonesia telah mencapai 659 jurnal yang masih stagnan pada angka 74 jurnal. Hal ini menjadi potensi besar bagi kepala sekolah untuk melakukan publikasi hasil risetnya di berbagai jurnal terindeks DOAJ di Indonesia.

\section{Journals' Growth in DOAJ by Country}

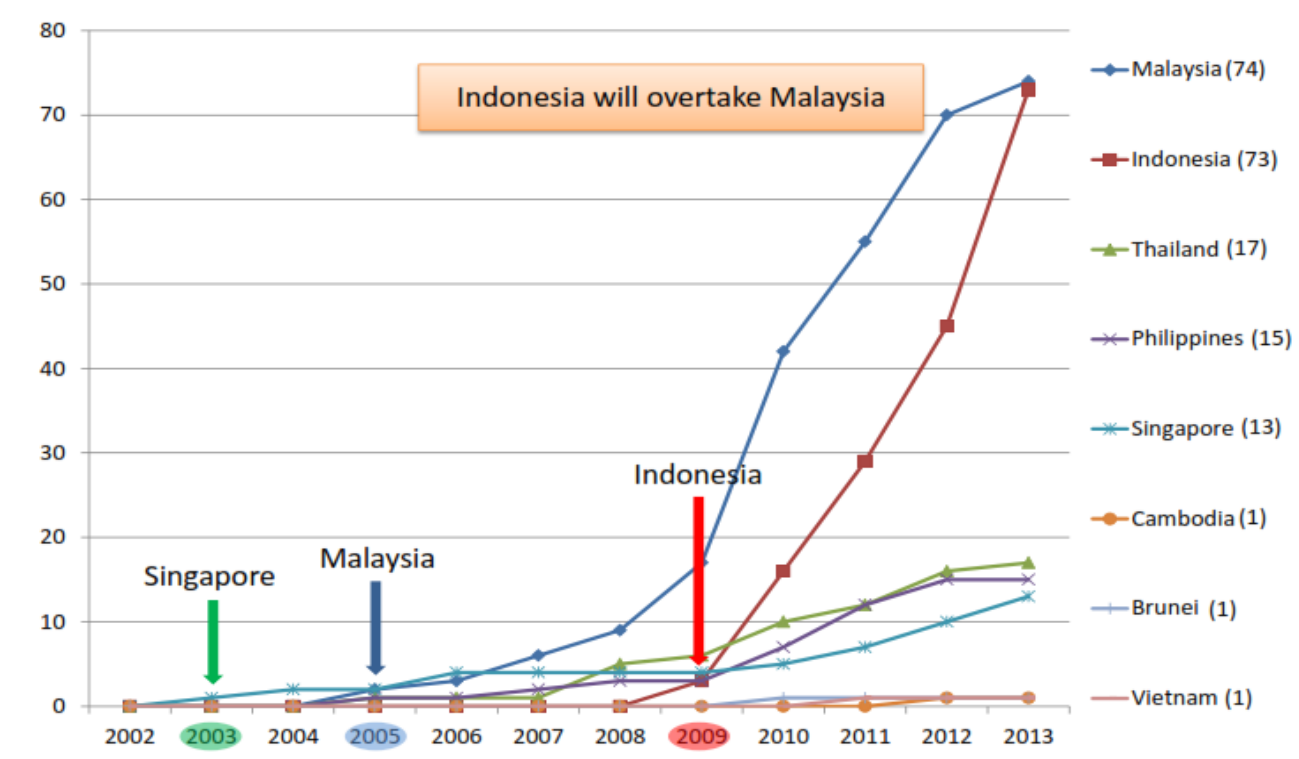

http://www.doaj.org/doaj?func=byCountry\&uiLanguage=en

Grafik 1. Pertumbuhan jurnal terindeks DOAJ 
Selain itu, terdapat berbagai macam teknik dan cara untuk membantu kepala sekolah dalam menyusun artikel ilmiah tersebut. Salah satu langkahnya adalah penggunaan aplikasi pengutipan digital. Sehingga dengan adanya software tersebut, guru BK/Konselor akan lebih mudah dalam melakukan penyusunan hasil artikel ilmiahnya. Namun, sosialisasi dan penggunaan aplikasi ini masih minim di lapangan

\section{Metodologi}

Prosedur pengabdian ini termasuk ke dalam kegiatan sosialisasi penulisan artikel ilmiah dan pengutipan digital dengan metode workshop. Pengumpulan data dilakukan secara kualitatif dengan menggunakan analisis hasil wawancara dan observasi terhadap peserta kegiatan.

\section{Hasil dan Pembahasan}

Pemahaman kepala sekolah bisa ditingkatkan dengan memberikan pelatihan berupa pengenalan, pemberian pengetahuan dan wawasan kepada kepala sekolah yang nantinya dapat diaplikasikan untuk menulis artikel ilmiah. Materi disadur dari berbagai sumber mengenai pedoman penulisan artikel ilmiah, salah satunya adalah pedoman penulisan artikel ilmiah Fakultas Ilmu Pendidikan Universitas Negeri Padang

Dalam menulis artikel ilmiah, Kepala Sekolah dapat dibantu dengan berbagai software untuk melakukan pengutipan secara otomatis dan penyusunan kepustakaan. Pada pelatihan ini, aplikasi yang digunakan adalah Mendeley versi 1.15.3.

Mendeley merupakan salah satu aplikasi yang dapat digunakan untuk menyimpan literatur dan sumber penulisan dalam format digital. Aplikasi ini dapat digunakan untuk melakukan pengutipan, penulisan kepustakaan dan penyimpanan berkas.

Pemahaman kepala sekolah dan guru dapat ditingkatkan dengan memberikan pelatihan berupa pengenalan artikel ilmiah, dan pengenalan umum berbagai unsur dalam artikel ilmiah. Wawasan tentang berbagai bentuk artikel ilmiah dalam bidang pendidikan juga diberikan kepada kepala sekolah. Selain itu, kepala sekolah dan guru juga diberi pemahaman bahwa penulisan artikel ilmiah dan dipublikasikan dalam berbagai forum ilmiah merupakan salah satu unsur yang harus dipenuhi oleh guru sesuai dengan Permenpan Nomor 19 tahun 2009.

Pengetahuan dan pemahaman tentang kasus-kasus serta permasalahan yang terjadi di sekolah dapat diangkat sebagai topik/tema artikel tulis ilmiah adalah dengan melatih guru-guru tersebut melakukan identifikasi permasalahan dalam pelatihan. Selain itu, kepala sekolah juga dilatih dalam mengembangkan keterampilan penulisan artikel ilmiah berdasarkan hasil identifikasi permasalahan-permasalahan yang ditemui di lapangan.

Kegiatan persiapan untuk penerapan IPTEKS dilakukan dengan studi kebutuhan dan design bentuk kegiatan yang mungkin dilaksanakan, menentukan personil yang akan terlibat dan melakukan penyusunan proposal kegiatan penerapan IPTEKS. Setelah proposal disiapkan kegiatan berikutnya adalah melakukan koordinasi dengan Ketua Musyawarah Kerja Kepala Sekolah (MKKS) Kabupaten Lima Puluh Kota, hasil koordinasi dengan Ketua MKKS tersebut melahirkan kesepakatan dan kerjasama dengan sekolah penyelenggara kegiatan yakni di Gedung Pertemuan Shago Bungsu, Tanjuang Pati, Kab. Lima Puluh Kota. Selain itu kegiatan persiapan juga meliputi kegiatan pembentukan tim pelaksana kegiatan yang selanjutnya bertugas sebagai panitia yang akan membantu pelaksanaan kegiatan mulai dari mempersiapkan dan distribusinya undangan peserta, peminjaman ruangan dan alat-alat penunjang pelaksanaan kegiatan, penyiapan daftar hadir, kit kegiatan dan hal-hal lain yang mendukung suksesnya penyelenggaraan kegiatan.

Setelah melakukan koordinasi dengan MKKS Kabupaten Lima Puluh Kota, maka disepakati penyelenggaraan kegiatan ini akan dilaksanakan di Gedung Pertemuan Shago Bungsu, Tanjuang Pati, Kab. Lima Puluh Kota. Pihak sekolah memalui wakil kepala sekolah bidang humas menyatakan siap membantu menyukseskan kegiatan ini. Kegiatan inti diselenggarakan pada hari Rabu, 20 September 2017 dengan peserta yang hadir sejumlah 44 orang dari rencana 50 Orang peserta. Kegiatan dilakukan dengan 
dibuka oleh Kepala Dinas Pendidikan Kabupaten Lima Puluh Kota dan Ketua MKKS Kab. Lima Puluh Kota. Dalam pelaksanaan kegiatan ini pada tahap awal diberikan materi yang selajutnya secara terkoordinasi akan dilaksanakan praktik di sekolah masing-masing. Selanjutnya juga dilakukan evaluasi kegiatan tahap awal yaitu, evaluasi segera dan evaluasi jangka pendek, dilakukan dengan cara menanyakan kepada peserta tentang pemahaman dan sarannya terhadap pelatihan segera setelah pelatihan usai. Dari hasil evaluasi diperoleh bahwa kepala sekolah umumnya merasa berterimakasih, karena memperoleh wawasan, pengetahuan, ketrampilan, nilai dan sikap baru untuk nantinya menjalankan perannya sebagai kepala sekolah.

\section{Kesimpulan}

Kegiatan pada tahap selanjutnya adalah tahap evaluasi jangka pendek, dalam evaluasi jangka pendek dilakukan dengan mengobservasi dan penyampaian kesan dan pesan peserta. Dari kegiatan ini diperoleh hasil bahwa peserta merasa bahagia dan berterimakasih atas diselenggarakannya kegiatan ini, dan terungkap harapan agar kegiatan serupa agar senantiasa dilakukan untuk peningkatan WPKNS para kepala sekolah, menuju optimalisasi pelayanan, peningkatan kompetensi dan kualitas pendidikan dan sekolah, dan khususnya konseling di Sekolah.

\section{Referensi}

Ardi, Z. (2012). Konseling Online: Sebuah Pendekatan Teknologi dalam Pelayanan Konseling. Seminar International Konseling MALINDO 2, 235-240.

Ardi, Z., \& Hariko, R. (2014). Gambaran Kegiatan Belajar Siswa Sumatera Barat.

Babbie, E. R. (2013). The basics of social research. Cengage Learning.

Daharnis, D., \& Ardi, Z. (2016). The Compatibility Student Choice of University Majoring; a Preliminary Studies. GUIDENA: Jurnal Ilmu Pendidikan, Psikologi, Bimbingan dan Konseling, 6(1), 101-109.

Dewanti, S. S. (2011). Mengembangkan kemampuan berpikir kritis mahasiswa Pendidikan Matematika sebagai calon pendidik karakter bangsa melalui pemecahan masalah.

Gunawan, H. (2012). Pendidikan Karakter. Bandung: Alfabeta.

Hillis, J. D., Leonhardt, B. L., Vohs, J. L., Buck, K. D., Salvatore, G., Popolo, R., ... Lysaker, P. H. (2015). Metacognitive reflective and insight therapy for people in early phase of a schizophrenia spectrum disorder. Journal of Clinical Psychology, 71(2), 125-135.

Indriati, E. (2002). Menulis Karya Ilmiah. Gramedia Pustaka Utama.

Irawan, P., \& Aslichati, L. (2014). Metode Penelitian Sosial.

Lakitan, B. (2010). Revitalisasi Kelembagaan Riset dan Pengembangan untuk Mendukung Sistem Inovasi Nasional. In Seminar Revitalisasi Kelembagaan Litbang yang diselenggarakan di Pascasarjana Universitas Sahid, Jakarta (Vol. 23).

Leong, F. (2014). Career development and vocational behavior of racial and ethnic minorities. Routledge.

Lever, J. J., Nes, E. H., Scheffer, M., \& Bascompte, J. (2014). The sudden collapse of pollinator communities. Ecology Letters, 17(3), 350-359.

Li-Chan, E. C. (2015). Bioactive peptides and protein hydrolysates: research trends and challenges for application as nutraceuticals and functional food ingredients. Current Opinion in Food Science, 1, 2837.

Marjohan. (2012). Biografi Keilmuan Prayitno dalam Ranah Konseling dan Pendidikan. Padang: UNP Press.

Rofiq, A. (2005). Pemberdayaan pesantren: menuju kemandirian dan profesionalisme santri dengen metode daurah kebudayaan. PT LKiS Pelangi Aksara.

Sanderson, S. C., Diefenbach, M. A., Zinberg, R., Horowitz, C. R., Smirnoff, M., Zweig, M., ... Richardson, L. D. (2013). Willingness to participate in genomics research and desire for personal 
results among underrepresented minority patients: a structured interview study. Journal of Community Genetics, 4(4), 469-482.

Sarwono, J. (2010). Pintar Menulis Karangan Ilmiah-Kunci Sukses dalam Menulis Ilmiah. Penerbit Andi.

SKOVHOLT, T., \& Jennings, L. (2017). Master therapists: Exploring expertise in therapy and counseling. Oxford University Press.

Suhartono, S. (2004). Dasar-dasar Filsafat. Jogjakarta: Ar-Ruzz.

Vucic, S., Rothstein, J. D., \& Kiernan, M. C. (2014). Advances in treating amyotrophic lateral sclerosis: insights from pathophysiological studies. Trends in Neurosciences, 37(8), 433-442. 